\title{
Failure to Cut
}

National Cancer Institute

\section{Source}

National Cancer Institute. Failure to Cut. NCI Thesaurus. Code C63188.

Inability of the device to make an incision, pierce or open as intended. 